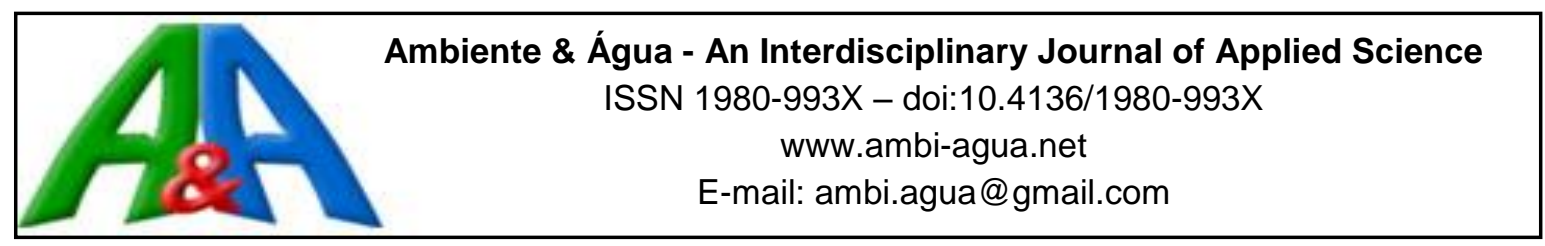

\title{
Heavy metals in the São Mateus Stream Basin, Peixe River Basin, Paraiba do Sul River Basin, Brazil
}

\author{
ARTICLES doi:10.4136/ambi-agua.2329
}

Received: 13 Sep. 2018; Accepted: 31 Mar. 2019

\author{
Cézar Henrique Barra Rocha ${ }^{1^{*} \text {; }}$; Hiago Fernandes Costa ${ }^{1}$; \\ Leonardo Pimenta Azevedo 2 (D)

\begin{abstract}
${ }^{1}$ Universidade Federal de Juiz de Fora (UFJF), Juiz de Fora, MG, Brasil Faculdade de Engenharia. Núcleo de Análise Geo Ambiental (NAGEA). E-mail: barra.rocha@gmail.com, hiagofc@hotmail.com ${ }^{2}$ Instituto Estadual de Florestas (IEF/MG), Viçosa, MG, Brasil Agência de Florestas e Biodiversidade. E-mail: leopimentaz@yahoo.com.br
\end{abstract} \\ *Corresponding author
}

\begin{abstract}
Large-scale enterprises with high potential to pollute need to be licensed, properly supervised and monitored during and after their operations to avoid and/or mitigate impacts in their areas of influence. The São Mateus Stream Basin (SMSB), located in rural area of Juiz de Fora (MG), is impacted by several activities, highlighting a deactivated landfill and an industrial park. This study monitored the concentration of heavy metals in the waters of the main tributaries of the SMSB. Strategic points were selected in each sub-basin, before the mouth and meeting of the Bocaina, Salvaterra and São Mateus Streams, measured monthly between January and December 2014 using the Metalyser probe, and applying the Contamination Index (CI). The CI results showed that the enterprises located in this basin, especially the Park Sul and Salvaterra Landfill in the Bocaina and Salvaterra Streams, respectively, are negatively impacting the quality of these waters. Metals such as $\mathrm{Hg}, \mathrm{Cu}, \mathrm{Pb}$ and $\mathrm{Zn}$ were the ones that most violated CONAMA Resolution 357/2005, directing management in order to control the sources of these metals, which are cumulative in organisms and damage the whole trophic chain. The inhabitants of this rural area are not served by any water concessionaire and make use of springs and wells below the level of these streams.
\end{abstract}

Keywords: contamination index, environmental impacts, environmental monitoring, landfill, water quality.

\section{Metais pesados na Bacia Hidrográfica do córrego São Mateus, Bacia do rio do Peixe, Bacia do rio Paraíba do Sul, Brasil}

\section{RESUMO}

Empreendimentos com porte e potencial poluidor precisam ser licenciados adequadamente, fiscalizados e monitorados durante e após suas operações de forma a evitar e/ou mitigar impactos nas suas áreas de influência. A Bacia Hidrográfica do córrego São Mateus (BHCSM), situada em zona rural de Juiz de Fora (MG), é impactada por várias atividades, destacando um aterro sanitário desativado e um parque industrial. $\mathrm{O}$ objetivo desse artigo foi monitorar as águas dos principais tributários da Bacia Hidrográfica do córrego São Mateus em

This is an Open Access article distributed under the terms of the Creative Commons Attribution License, which permits unrestricted use, distribution, and reproduction in any medium, provided the original work is properly cited. 
relação à concentração de metais pesados. Escolheram-se pontos estratégicos em cada subbacia, antes da foz e encontro dos córregos Bocaina, Salvaterra e São Mateus, mensurados mensalmente entre janeiro e dezembro de 2014 através da Sonda Metalyser, aplicando-se o Índice de Contaminação (IC). Os resultados do IC permitiram verificar que os empreendimentos localizados nesta Bacia, em especial, o Park Sul e o Aterro Sanitário Salvaterra nos córregos Bocaina e Salvaterra, respectivamente, estão impactando negativamente a qualidade dessas águas. Metais como $\mathrm{Hg}, \mathrm{Cu}, \mathrm{Pb}$ e $\mathrm{Zn}$ são os que mais violaram a Resolução CONAMA 357/2005, direcionando desta forma a gestão, de modo a controlar as fontes destes metais que são acumulativos nos organismos e geram prejuízos a toda cadeia trófica. A população que habita essa região rural não é atendida por nenhuma concessionária de água, fazendo uso de nascentes e poços abaixo do nível desses córregos.

Palavras-chave: aterro sanitário, impactos ambientais, índice de contaminação, monitoramento ambiental, qualidade da água.

\section{INTRODUCTION}

Population growth coupled with high consumption patterns and lack of recycling and reuse programs leads to increasing waste generation and the need for disposal areas. Due to the flaws in choosing these locations, undersized treatment projects and lack of maintenance, slurry is generated which flows into nearby areas, contaminating water resources. Santana and Barroncas (2007) define slurry as a dark-colored liquid resulting from the decomposition of organic matter present in garbage. The slurry is highly toxic; its composition is varied, and depends on factors such as the type of waste and the age of the landfill site. The release of slurry can also reach underground waters, contaminating these waters compromising their use.

Particularly, heavy metals are often found in the composition of much industrial and urban waste taken to municipal landfills. The high levels of toxicity of heavy metals to organisms, associated with their relative ease of entering and accumulating along trophic chains for a long time, underlies the importance of studies that determine their concentrations in aquatic environments. Manoj et al. (2012) reinforce that heavy metals enter the food chain and cause metabolic and physiological disturbances in organisms.

In this context, the monitoring of the São Mateus Stream Basin (SMSB) is important, considering all the negative impacts already created by the Salvaterra Landfill in the stream mentioned above. This basin also includes the Industrial District Park Sul, with emphasis on the exploitation of gravel and industrial sand in the Pedra Sul Quarry with the discharge of mineral tailings in the Bocaina Stream Basin, one of the tributaries of the Salvaterra Stream. The latter flows into the São Mateus Stream, which has its mouth in the Peixe River, a tributary of the Paraibuna River, one of the main ones in the Paraíba do Sul River Basin (Figure 1).

From January 1999 to 04/11/2010, the date of deactivation of the landfill, all domestic, hospital and industrial waste from Juiz de Fora was deposited at Salvaterra Landfill, about 500 tons/day. Initially as a dump, intermediately as a Controlled Landfill and only in the final years, since 05/30/2005, as a landfill on the right slope. The area is on the banks of BR040, has rugged relief and had several springs, contrary to the technical and legal requirements for locating an enterprise for this purpose. During the period of operation of the Salvaterra landfill there were several irregularities, such as burial, contamination of springs and water table, risk of accidents with trucks that transported the slurry produced by the landfill to the Sewage Treatment Station (STS) in the Barbosa Laje Neighborhood, and health risks to the local population due to contamination of the shallow wells of the region, since it does not have a water supply and therefore depends on the water of wells and springs, almost always at a lower elevation than this landfill. The possible lack of compatibility between the treatment of slurry

Rev. Ambient. Água vol. 14 n. 3, e2329 - Taubaté 2019 
in the Barbosa Laje STS and the accumulation capacity of the percolated tanks present in this landfill may explain possible spillages of manure in the waters of the Salvaterra Stream, which also has two of its sources within the limits of Salvaterra Landfill.

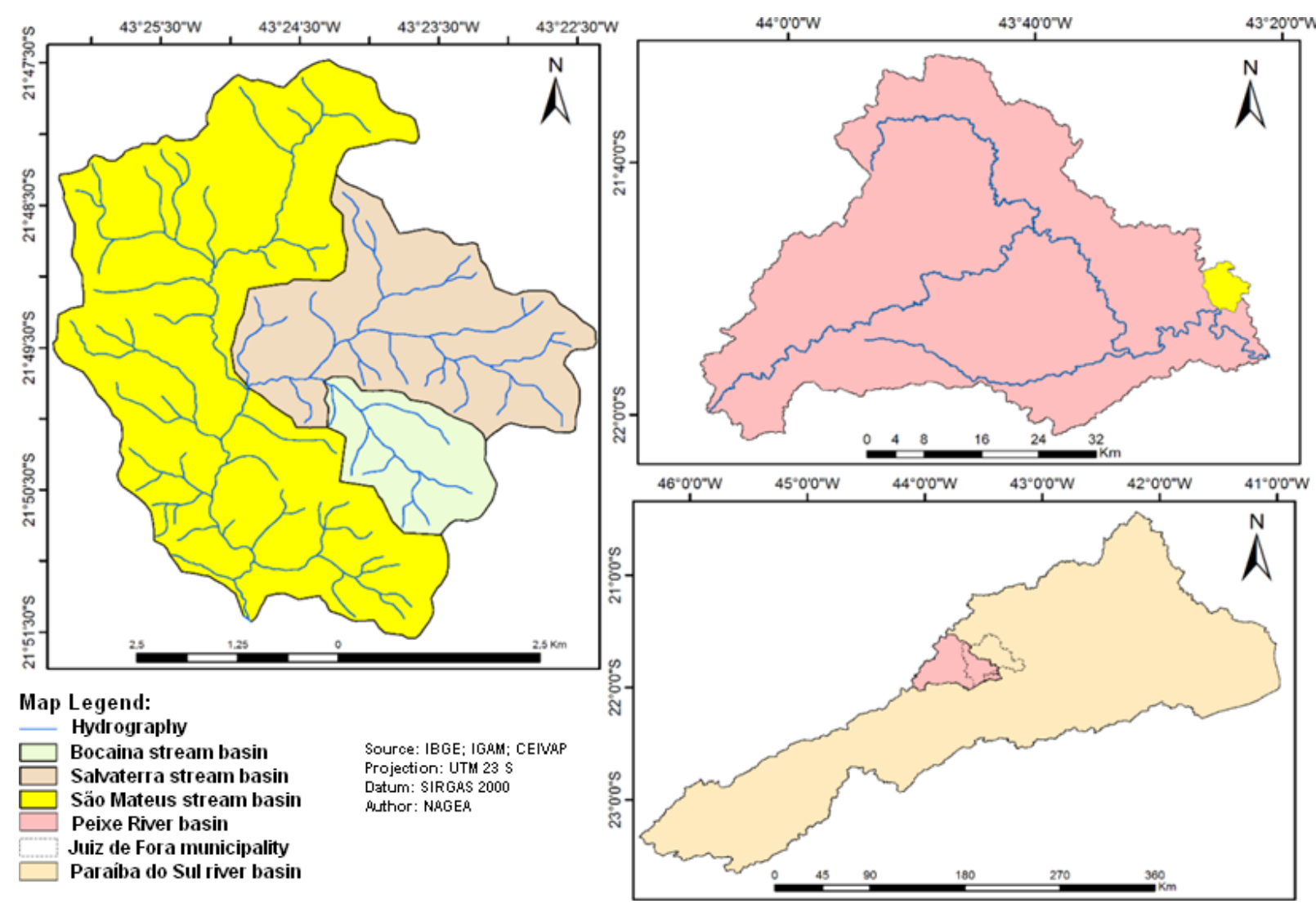

Figure 1. Location of the São Mateus River Basin in the Rio do Peixe watershed, Juiz de Fora and Paraíba do Sul River Basin.

For Guedes et al. (2012), Rocha et al. (2014) and Rocha and Pereira (2016), the monitoring of water quality is one of the main instruments for sustaining and managing water resources, functioning as a tool to identify the effects of use on water quality, assisting in environmental control actions.

Therefore, this study monitored the waters of the main tributaries of the São Mateus Stream to determine the concentrations of heavy metals by applying the Contamination Index (CI).

\section{MATERIAL E METHODS}

In order to verify and understand the processes that affect the São Mateus Stream Basin, monthly collections were carried out from January to December 2014 at three strategic points: Point 1 (P1) in the São Mateus Stream prior to the encounter with the Salvaterra Creek; Point 2 (P2) in the Salvaterra Stream before the encounter with the Bocaina Stream; and Point 3 (P3), mouth of the Bocaina Stream before the encounter with Salvaterra. The three points monitored, as well as the location of the Salvaterra Landfill and the Park South complex are illustrated in Figure 2. 


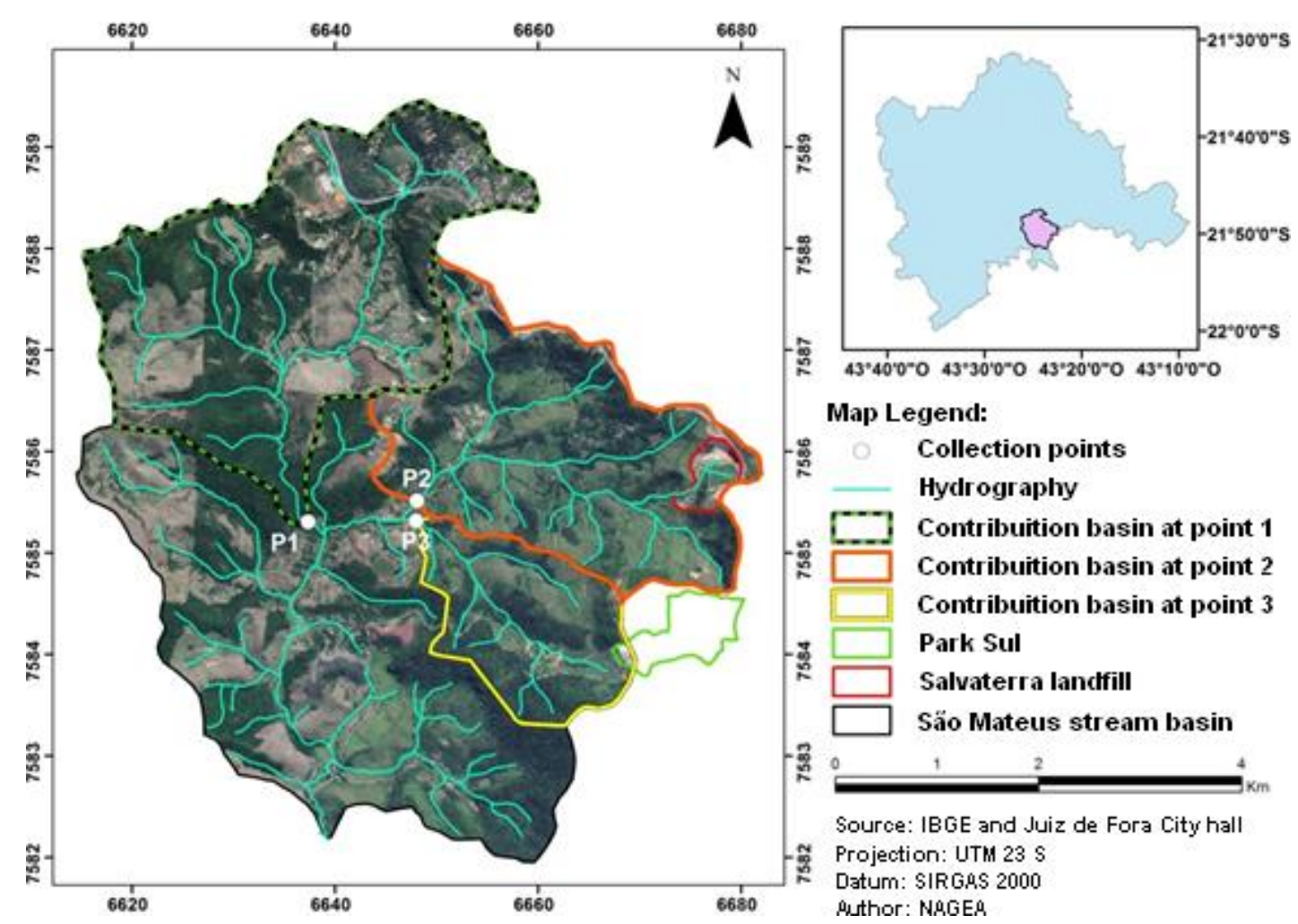

Figure 2. São Mateus Stream Basin, contribution basins of collection points, Salvaterra landfill and Park Sul within the limits of Juiz de Fora.

The São Mateus Stream Hydrographic Basin extends from the source of the São Mateus Stream, located in Nova California neighborhood, to the mouth of Peixe River, which is classified as Class 1, according to the COPAM (State Council for Environmental Policy) Normative Resolution Number 16 of September 25, 1996 (Copam, 1996). According to this classification, Peixe River can be used for human supply after simplified treatment, recreation of primary contact and irrigation. The watershed area of the São Mateus Stream is approximately $30 \mathrm{~km}^{2}$, and its two main tributaries are the Salvaterra (P2 sub-basin) and Bocaina (P3 sub-basin) Streams.

The BR-040 and MG-353 are the main highways that cross the São Mateus Basin, which also includes the Salvaterra Valley Private Natural Heritage Reserve (RPPN). This RPPN is formed by natural environments typical of the remnants of the Atlantic Forest, this being the important private reserve of the municipality of Juiz de Fora with considerable vegetation, as shown in Figure 2.

The samples were collected in plastic containers with a capacity of 2 liters and later analyzed in the laboratory. Only heavy metals were monitored by means of the CLEAN Metalyser HM 1000 probe that determines 6 parameters in parts per billion (ppb) or Micrograms / liter ( $\mu \mathrm{g} \mathrm{L}^{-1}$ ), being: Arsenic III (As III), Total Cadmium (Cd), Total Lead (Pb), Total Copper $(\mathrm{Cu})$, Total Mercury ( $\mathrm{Hg}$ ) and Total Zinc (Zn). The detection limit of the probe for As (III), Cu, $\mathrm{Hg}, \mathrm{Pb}$ and $\mathrm{Zn}$ metals ranges from $5 \mathrm{ppb}$ up to $500 \mathrm{ppb}$ and for $\mathrm{Cd}$ ranges from $3 \mathrm{ppb}$ up to 500 ppb.

After obtaining the results, the data were tabulated in Microsoft Office Excel 2010 and analyzed through the application of descriptive statistics and application of the Contamination Index.

For the calculation of the Contamination Index (CI), the Contamination Factor (CF) was first determined through the method used by Manoj et al. (2012). Ribeiro et al. (2012) proposed using the relationship between the concentrations of the metals found in the sample and 
reference concentrations, that is, concentrations that would be expected for that particular site, as shown in Equation 1. Thus, as in Ribeiro et al. (2012), in this work, the limits established by CONAMA Resolution 357/2005 (Conama, 2005) for fresh waters classified as Class 1 were used as reference values. These limits were converted from $\mathrm{mg} / \mathrm{L}$ to $\mathrm{ppb}$ by multiplying by 1000. The contamination factors were determined for each of the metals, for each month and for each of the three points sampled.

$\mathrm{CF}=($ Concentration of sampled point $(\mathrm{ppb}))$

$\overline{\text { (Maximum concentration allowed by CONAMA 357/2005 (ppb)) }}$

The Contamination Factor seeks to determine the number of times the limit value established by environmental legislation, in the case of CONAMA 357/2005, has been exceeded or not. Therefore, if $\mathrm{CF}>1$, the reference value exceeds the concentration found in the sample; but if $\mathrm{CF}=1$, both concentrations, that is, found in the sample and allowed in the legislation, are equal; and $\mathrm{CF}<1$, indicates that the concentration of the metals determined in the sample was lower than that established in the legislation.

After the calculation of the Contamination Factor (CF), the Contamination Index (CI) was calculated, which sums up the sum of the contamination factors of the six metals analyzed in each month for each of the three points according to Equation 2.

$$
C I=\sum_{i=1}^{n} C F
$$

The Contamination Index accumulates the contamination factors, which the greater they appear, that is, the more they exceed the maximum concentration allowed by CONAMA $357 / 2005$, the more they contribute to the high value of the Contamination Index, and the worse the degree of contamination in the water studied.

It is worth noting that the probe used gives the total concentrations of the metals $\mathrm{Cu}, \mathrm{Cd}$, $\mathrm{Zn}, \mathrm{Pb}$ and $\mathrm{Hg}$ and the concentration of As III, and that the CONAMA 357/2005 resolution establishes limits for dissolved copper and not total copper and total arsenic and not arsenic III. In spite of this difference, in this work the $\mathrm{Cu}$ data obtained by the probe were compared to the limit of the CONAMA resolution 357/2005 for dissolved $\mathrm{Cu}$, since its presence or absence would little change the Contamination Indices and would change the classification only for the months of Sep / 14 in the São Mateus Stream and Dec / 14 in Salvaterra Stream that would pass from the average classification to good, but this data was maintained to highlight the presence of the same in the studied waters. As for As III, when only a fraction of the metal is compared to the total and this ratio is higher than 1, we will be underestimating the presence of Arsenic, since the Arsenic V (As V) fraction that together with As III form As Total is not being detected by the probe, which if detected could raise the Contamination Index.

In order to perform the calculations, it was considered that values below the detection limit would be equal to zero, which ultimately underestimates the results, since although the concentrations in this case are very low, the metals may be present and not contribute to the IC. Furthermore, values above the limit of detection were considered as $500 \mathrm{ppb}$.

After the calculations, the months of each point were classified according to the four categories proposed by Ribeiro et al. (2012), described in Table 1.

Table 1. Classification of Contamination Index.

\begin{tabular}{cc}
\hline Contamination index & Classification \\
\hline $0<=10$ & Good \\
$10<=50$ & Average \\
$50<=100$ & Uncertain \\
\hline
\end{tabular}

Source: Adapted from Ribeiro et al. (2012). 


\section{RESULTS AND DISCUSSION}

According to Figure $3 \mathrm{~b}$ and $3 \mathrm{e}, \mathrm{Cu}$ and $\mathrm{Hg}$ were repeatedly above legal limits at all three points. For Hg (Figure 3e), concentrations up to 90, 80 and 10 times the CONAMA 357/2005 limit were punctually observed for P3, P2 and P1, respectively. Zn (Figure 3a) and Cu (Figure $3 \mathrm{~b}$ ) were detected in almost all water samples, being most of the time above than the CONAMA limit for $\mathrm{Cu}$ at the three points while $\mathrm{Zn}$ was generally inferior. Cadmium (Figure 3c), Lead (Figure 3d) and Arsenic III (Figure 3f) were not always detected, but were almost each time over the legal limit when they were. The points most-impacted by $\mathrm{Cd}$ and $\mathrm{Pb}$ were $\mathrm{P} 2$ and $\mathrm{P} 3$. During all the sampling, As (III) was only detected three times: two times at P1 (São Mateus Stream) and one at P2 (Salvaterra Stream).
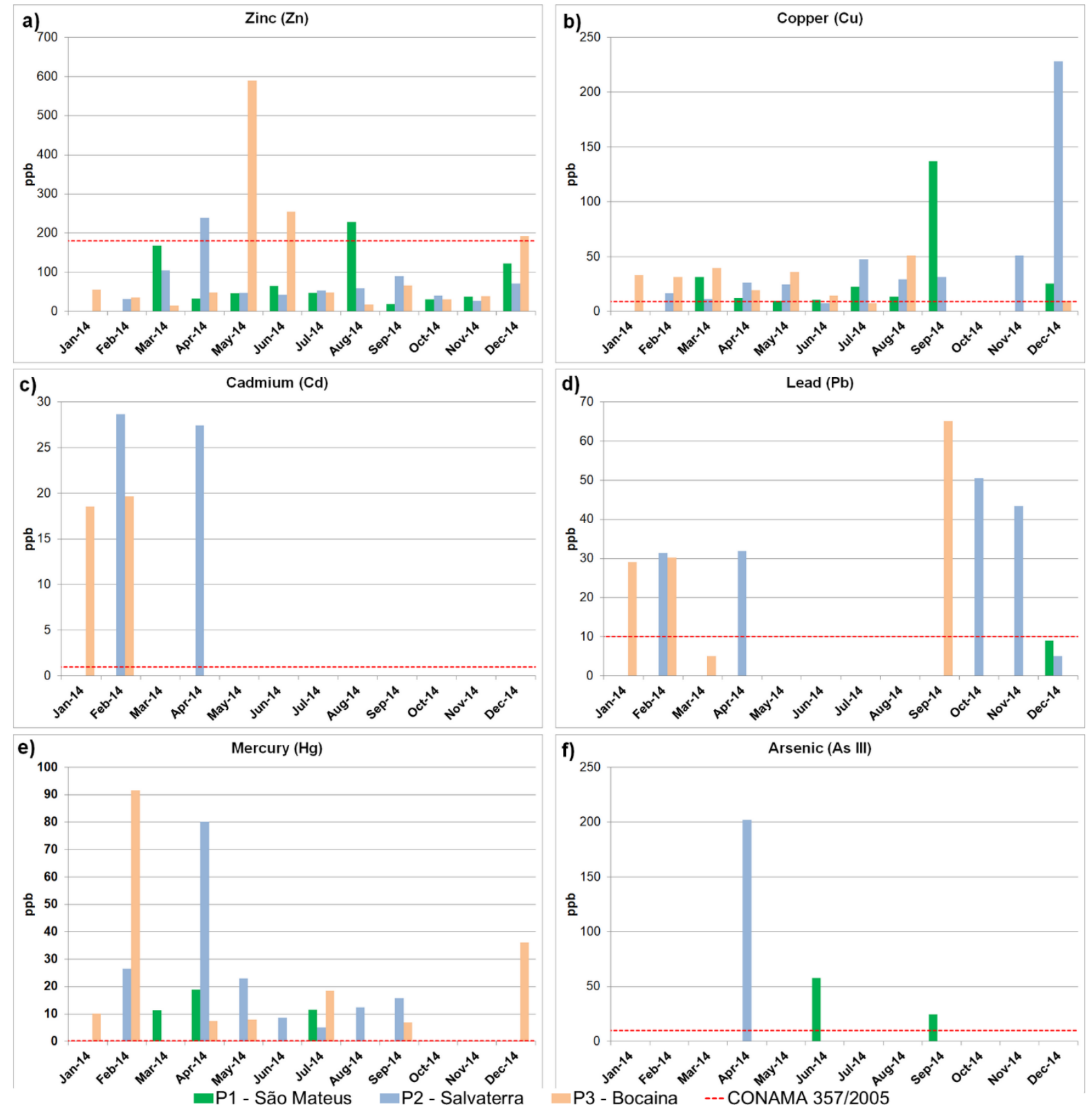

Figure 3. Monthly evolution of Zinc (a), Copper (b), Cadmium (c), Lead (d), Mercury (e) and Arsenic (f) concentrations at three points during the year 2014.

From the results obtained in the calculation of the Contamination Factor (FC) for the three 
points studied, it was possible to detect that $31.3 \%$ of the concentrations of the metals analyzed were above the limits established by CONAMA resolution 357/2005, since they presented values of $\mathrm{CF}$ above 1 . After the calculations of the Contamination Indices for all the points monitored during the study period, several results were obtained, with indices of good quality and bad quality found, as shown in Table 2, which shows the average of the Contamination Indices of each point, resulting in an average quality for the São Mateus Stream and an uncertain quality for the Salvaterra and Bocaina Streams. Salvaterra's index was slightly higher than that of Bocaina. There is also a very marked variation between the Contamination Indices from one month to the other in the points studied, which is due to possible variations in the flow of water courses, the variation of manure discharges in the case of the Salvaterra Creek and the incorporation of the metals in the sediments and their resuspension, which are quite random factors that depend on the dynamics of the basin. According to Cotta et al. (2006), after sedimentation, metals may again become available in water due to oxy-reduction reactions or resuspension processes caused by the current or activity of organisms that inhabit the sediment.

Table 2. Contamination Index found in the three monitored points.

\begin{tabular}{lccc}
\hline \multicolumn{4}{c}{ Contamination index } \\
\hline & São Mateus & Salvaterra & Bocaina \\
\cline { 2 - 4 } Months & P1 & P2 & P3 \\
\hline Jan-14 & & & 76 \\
Feb-14 & 61 & 167 & 484 \\
Mar-14 & 96 & 2 & 5 \\
Apr-14 & 1 & 455 & 40 \\
May-14 & 7 & 118 & 47 \\
Jun-14 & 61 & 45 & 3 \\
Jul-14 & 3 & 31 & 94 \\
Aug-14 & 18 & 65 & 6 \\
Sep-14 & 0 & 83 & 42 \\
Oct-14 & 0 & 5 & 49 \\
Nov-14 & 4 & 10 & 0 \\
Dec-14 & 25 & 26 & 182 \\
\hline Average of each stream & & 92 & 86 \\
\hline
\end{tabular}

The average CIs in the rainy months, which according to the Urban Development Master Plan of the city of Juiz de Fora (Juiz de Fora, 2000) are the months of October to April, are worse than in the dry months, which possibly due to the loading of materials into the body of water, such as household waste, residues from the Pedra Sul quarry, transport of fertilizers and domestic sewage and other elements that include heavy metals. According to Vasco et al. (2011), surface runoff of water on the ground during rainfall is the main diffuse source of pollution of water bodies. This fact denotes the importance of maintaining the riparian forests, which according to Rocha and Costa (2015) are similar to the safety bands of highways and firebreaks in parks, as they function as safety bands for the quality of the water body, reducing the impact of pollution sources through the "filter" effect, highlighting the improvement of air quality, the retention of fine sediments, toxic products and nutrients carried by precipitation, minimizing the silting of the waterbody, avoiding erosion and stabilizing the soils of the margins, constituting of a true physical barrier. Lima and Santos (2012) attributed the increase in the concentration of metals in the waters of Claro River in the state of Goiás to the absence of riparian forest at its margins.

Based on the average results found in the points, it was possible to observe that P2 and P3 
are actually more impacted because they present the highest contamination indexes, which is due in large part to the ventures present in their sub-basins. This contamination can spread not only by surface water, but also can reach the water table, a possible source of water for the local population. Oliveira and Pasqual (2004), Lopes et al. (2007) and Nakamura et al. (2014), verified the contamination of the water table by heavy metals in their stidies.

Arsenic, Cadmium, Lead, Copper, Mercury and Zinc are systematically referred to as sources of urban waste deposited in landfills or dumps, domestic sewage, mining, industrial dumping and agricultural activities (Campos et al., 2009; Coelho, 2012; Cotta et al., 2006; Egreja Filho et al., 1999; Jesus et al., 2004; Lima and Santos, 2012; Macêdo, 2007; Marins et al., 2004; Nakamura et al., 2014; Nriagu e Pacyna, 1988; Ribeiro et al., 2012; Santana and Barroncas, 2007; Silva et al., 2016; WHO, 2004; 2007; 2010a; 2010b; 2010c; Yu et al., 2014).

P1 in the São Mateus Stream was the point that presented a better quality of water, and bad quality was not detected at any time despite having high Contamination Indices in the first two months studied (March and April / 2014). Hg was presence in high concentrations. In addition, $\mathrm{Cu}$ and $\mathrm{Zn}$ were also detected more frequently, and occurred together with $\mathrm{Hg}$ in the formation of almost all Contamination Indices. As was most relevant only in the month of July, possibly associated with agricultural use in the Sub-basin of contribution of the São Mateus Stream, since Arsenic is present in elements such as fertilizers, herbicides and pesticides.

Despite the use of fertilizers and sewage, these sources did not significantly influence the presence of $\mathrm{Pb}$ in water, since it was detected only in December and at a concentration below the limits established by CONAMA Resolution 357/2005. At this point, Cadmium was not found in any sample, possibly due to the fact that it occurs in very low concentrations in natural waters. $\mathrm{Cu}$ is also not found significantly in natural waters; however, it was not present only in two months of the year, and when it was found it was always above the limit established by CONAMA 357/2005.

In this way, it can be noticed that the contribution of domestic sewage and agricultural activities to the concentrations of heavy metals in P1 occurs due to the high concentration of $\mathrm{Hg}, \mathrm{Cu}$ and $\mathrm{Zn}$, which have domestic sewage as a common source (Jackson, 1992), and agricultural activities, through the use of pesticides, fertilizers, insecticides, among others (Gonçalves Júnior et al., 2014; Nacke et al., 2013; Silva et al., 2016; 2018).

P2 was the point that presented the most months classified as bad and the lowest number of months classified as good, which in fact confirms the degradation of the same, mainly because it was the only point in which were present all of the metals analyzed in the samples, i.e., the heavy metals $\mathrm{Hg}, \mathrm{Cu}, \mathrm{Zn}$ and $\mathrm{Pb}$, the main ones responsible for the formation of Contamination Indices throughout the studied period. In April, in P2 a dark was detected at the time of collection. This supposedly was a spill of slurry occurred near dawn. According to Celere et al. (2007), several organic and inorganic substances are carried by slurry. Campos et al. (2009) highlights that slurry is an extremely polluting and damaging liquid with high organic load and heavy metals, the latter with bioaccumulative characteristics. Heavy metals in large concentrations deserve greater attention because of their non-degradability, remaining in the environment for a long time (Cotta et al., 2006).

$\mathrm{Hg}$ is a highly toxic metal and harmful to human health even in low concentrations. Due to the low concentration allowed in legislation for this heavy metal, when present it was primarily responsible for values of the Contamination Index, mainly in the points P2 and P3, revealing that the index is coherent, since the presence of $\mathrm{Hg}$ in the water is extremely dangerous and undesirable. At P2 in April, the month in which the spill was supposed to have occurred, the $\mathrm{Hg}$ exceeded by about 400 times the limit of legislation, while at P3 in February the limit was exceeded 457 times.

Thus, the presence of metals $\mathrm{Hg}, \mathrm{Cu}, \mathrm{Zn}$ and $\mathrm{Pb}$ with higher frequency and higher 
concentrations in P2, as well as the dark water in the month of April at the time of collection, which presented all the heavy metals analyzed in this work, indicate that Salvaterra Landfill would be the main source of contamination of the Salvaterra Stream, mainly due to the disposal of materials such as batteries, light bulbs, electronic garbage, metal alloys, health care waste, and ferrous metals in general which partly comprise the slurry and subsequently reach the bodies of water. There may also be a contribution from domestic sewage and agricultural activities, but they become insignificant due to the contribution of Aterro Salvaterra.

Sisinno and Moreira (1996) found $\mathrm{Pb}$ above that allowed by regulation in wells and springs in the area of influence of the Controlled Landfill of Morro do Céu in Niterói in the state of Rio de Janeiro. $\mathrm{Pb}$ was one of the main elements responsible for the values of the P2 Contamination Index; this fact is possibly due to the deposition of residues such as batteries, electric appliances, cables and paints in the Salvaterra Aterro that include this element, and that eventually leach into the waters of the stream. According to CETESB (2009), Pb can affect almost all organs of the body, especially the nervous system, both in adults and children, besides accumulating in the body causing toxification. Once absorbed, it can be found in blood, soft tissues and bone (ATSDR, 2012).

It is interesting to note that Arsenic is very much attributed to the spillage of manure, since the only time it was found in P2 was the month in which the dark waters were observed, presumably due to the presence of manure, although we underestimated such concentration due to the detection of only one of the fractions of As Total. Soon, As was one of the smallest contaminants in the analyzed waters. According to Macêdo (2007), Arsenic is rare in natural waters.

In P3, the Contamination Index was also high, presenting water as of bad quality at two different times, in February and December, both in the rainy season and as good quality in four months of the year. At this point, only Arsenic was not found, whereas the other metals, mainly, $\mathrm{Hg}, \mathrm{Cu}$ and $\mathrm{Zn}$ formed a large part of the Contamination Indices. The possible cause of $\mathrm{Hg}$ contamination was not clearly found, but it is possible that domestic sewage was discharged into this stream, which is the possible source of this metal that was detected more frequently at this point. $\mathrm{Cu}$ may be associated with mining, that is, the production of industrial sand and gravel in the sub-basin, since this metal appears very frequently in this stream. $\mathrm{Zn}$ was the only metal that exceeded the detection limit of the probe, although this occurred only once in May at P3. This metal is found in the natural waters, and if it presents with concentrations above $5 \mathrm{mg} \mathrm{L}^{-1}$, it can affect water taste. This was the only metal that was present in the monitored points every month, and in a few months, Zn exceeded the limit of Conama Resolution $357 / 2005$. It is possible to explain the presence of this heavy metal in all samples, since according to Coelho (2012), $\mathrm{Zn}$ is readily transported in natural waters, being one of the most mobile heavy metals. According to Coelho (2012), Zinc is an essential and beneficial element to the human organism, but is toxic in high concentrations.

The occurrence of Cd only in the months of January and February in P3 may be associated with the exploitation of industrial sand and gravel in Pedreira Pedra Sul or the excessive use of fertilizers (Benson et al., 2014; Balkhair and Ashraf, 2016) in agricultural activities that also occur in this sub-basin. Cd contamination was not associated with the domestic sewage discharge because it was not seen in P1 and had not been continuously detected in other months, considering that domestic sewage is continuously released. This metal had little influence on the formation of P2 and P3 Contamination Indices, but when it was present in these points the limit established by CONAMA Resolution 357/2005 was exceeded. Manoj et al. (2012) reports that, in addition to $\mathrm{Hg}$ and $\mathrm{Pb}, \mathrm{Cd}$ is toxic even in minimal concentrations. According to Mcgrath et al. (2006), it may cause poisoning if ingested through water or food, in addition to being a carcinogenic element (Kumar Sharma et al., 2007).

In P3, although quarrying was one of the possible origins of Arsenic, this metal was not 
detected, possibly due to the absence of this metal in the rock formations. Therefore, in P3, mining from the South Park or agricultural activities in the sub-basin of the Bocaina Stream may contribute to the contamination by heavy metals.

\section{CONCLUSION}

The evaluation of Contamination Indices made it possible to verify that the ventures located in the São Mateus Stream Basin, especially the South Park and the Salvaterra Landfill in the Bocaina and Salvaterra Stream sub-basins, respectively, are in fact negatively impacting water quality. This impact may harm the entire trophic chain in the sub-basins of these two streams, more seriously than in the São Mateus Stream that is impacted by sewage and agricultural activities. Thus, the Contamination Index allowed us to identify that metals like $\mathrm{Hg}, \mathrm{Cu}, \mathrm{Pb}$ and $\mathrm{Zn}$ most violate CONAMA Resolution 357/2005, thus identifying the need for management in order to control the sources of these metals that are cumulative in organisms and generate losses in the medium- and long term.

\section{ACKNOWLEDGMENTS}

The authors would like to thank a Federal University of Juiz de Fora for research grants awarded and the researchers of Environmental Geo Analysis Core.

\section{REFERENCES}

ATSDR. Public Health Service. Atlanta, 2012.

BALKHAIR, K. S.; ASHRAF, M. A. Field accumulation risks of heavy metals in soil and vegetable crop irrigated with sewage water in western region of Saudi Arabia. Journal of Biological Sciences, v. 23, n. 3, p. 32-44, 2016. https://doi.org/10.1016/j.sjbs.2015.09.023

BENSON, N. U.; ANAKE, W. U.; ETESIN, U. M. Trace Metals Levels in Inorganic Fertilizers Commercially Available in Nigeria. Journal of Scientific Research \& Reports, v. 3, n. 4, p. 610-620, 2014.CAMPOS, A. E. L.; NUNES, G. S.; OLIVEIRA, J. C. S.; TOSCANO, I. A. S. Avaliação da contaminação do Igarapé do Sabino (Bacia do Rio Tibiri) por metais pesados, originados dos resíduos e efluentes do aterro da ribeira, em São Luís, Maranhão. Revista Química Nova, v. 32, n.4, p.960-964, 2009. http://dx.doi.org/10.1590/S0100-40422009000400025

CELERE, M. S.; OLIVEIRA, A. da S.; TREVILATO, T. M. B.; MUÑOZ, S. I. S. Metais presentes no chorume coletado no aterro sanitário de Ribeirão Preto, São Paulo, Brasil, e sua relevância para saúde pública. Caderno saúde Pública, v. 23, n. 4, p. 939-947, 2007.

CETESB. Significado ambiental e sanitário das variáveis de qualidade das águas e dos sedimentos e metodologias analíticas e de amostragem no Estado de São Paulo. São Paulo: SMA, 2009.

COELHO, V. M. B. Paraíba do Sul: um rio estratégico. Rio de Janeiro: Casa da Palavra, 2012. p. 143-182.

CONSELHO NACIONAL DE MEIO AMBIENTE. Resolução n 357 de março de 2005. Dispõe sobre a classificação dos corpos de água e diretrizes ambientais para o seu enquadramento, bem como estabelece as condições e padrões de lançamento de efluentes, e dá outras providências. Diário Oficial [da] União, Brasília, n. 53, 18 mar. 2005. 
COMISSÃO DE POLÍTICA AMBIENTAL (MG) - COPAM. Dispõe sobre o enquadramento das águas estaduais da bacia do rio Paraibuna. Deliberação Normativa n. 16, de 24 de setembro de 1996. Available at: http://www.siam.mg.gov.br/sla/download.pdf?idNorma=113. Access: 9 Feb. 2015.

COTTA, J. A. O.; REZENDE, M. O. O.; PIOVANI, M. R. Avaliação do teor de metais em sedimento do rio Betari no Parque Estadual Turístico do Alto Ribeira - PETAR, São Paulo, Brasil. Revista Química Nova, v. 29, n. 1, p. 40-45, 2006.

EGREJA FILHO, F. B.; REIS, E. L.; JORDÃO, C. P.; NETO, J. T. P. Avaliação quimiométrica da distribuição de metais pesados em compostos de lixo urbano domiciliar. Revista Química Nova, v. 22, n. 3, p. 324-328, 1999.

GONÇALVES JÚNIOR, A. C.; NACKE, H.; SCHWANTES, D.; COELHO, G. F. Heavy metal contamination in brazilian agricultural soils due to application of fertilizers. In: HERNANDEZ-SORIANO, M. C. (Ed.). Environmental risk assessment of soil contamination. Rijeka: Intech Open, 2014. p. 105-135.

GUEDES, H. A. S.; SILVA, D. D.; ELESBON, A. A. A.; RIBEIRO, C. B. M.; MATOS, A. T.; SOARES, J. H. P. Aplicação da análise estatística multivariada no estudo da qualidade da água do Rio Pomba, MG. Revista Brasileira de Engenharia Agrícola e Ambiental, v. 16, n. 5, p. 558-563, 2012. http://dx.doi.org/10.1590/S1415-43662012000500012

JACKSON, J. Heavy metals and other inorganic toxic substances. In: MATSUI, S. (Ed.). Guidelines of lake management. v. 4. Toxic substances management in lakes and reservoirs. Otsu: ILEC/UNEP, 1992. p. 65-80.

JESUS, H. C.; COSTA, E. de A.; MENDONÇA, A. S. F.; ZANDONADE, E. Distribuição de metais pesados em sedimentos do sistema estuarino da Ilha de Vitória-ES. Revista Química Nova, v. 27, n. 3, p. 378-386, 2004.

JUIZ DE FORA. Lei $\mathbf{n}^{\circ} 9.811$ de 27 de junho de 2000. Institui o plano diretor de desenvolvimento urbano de Juiz de Fora. 2000. Available at: http://www.jflegis.pjf.mg.gov.br/c_norma.php?chave=0000023630. Access: 07 May 2014.

KUMAR SHARMA, R.; AGRAWAL, M.; MARSHALL, F. Heavy metal contamination of soil and vegetables in suburban areas of Varanasi, India. Ecotoxicology and Environmental Safety, v. 66, n. 2, p. 258-266. 2007. https://doi.org/10.1016/j.ecoenv.2005.11.007

LIMA, A. M.; SANTOS, F. F. Análise das propriedades físico-químicas e de metais potencialmente tóxicos na água do rio Claro, próximo a cidade de Jataí - GO. Revista Ciências Exatas e Naturais, v. 14, n. 2, p. 239-255, 2012.

LOPES, A. A.; BRIGANTE, J. SCHALCH, V. Influência do aterro sanitário de São Carlos (SP), Brasil, na qualidade das águas superficial e subterrânea. Journal of Brazilian Society of Ecotoxicology, v. 2, n. 2, p. 115-127, 2007.

MARINS, R. V.; PAULA FILHO, F. J.; MAIA, S. R. R.; LACERDA, L. D.; MARQUES, W. S. Distribuição de Mercúrio Total como indicador de poluição urbana e industrial na costa brasileira. Revista Química Nova, v. 27, n. 5, p. 763-770, 2004. http://dx.doi.org/10.1590/S0100-40422004000500016

MACÊDO, J. A. B. Águas \& águas. 3. ed. Belo Horizonte: CRQ-MG, 2007. p. 137-288.

MANOJ, K.; KUMAR, B. PADHY, P. K. Characterisation of Metals in Water and Sediments of Subarnarekha River along the Project's Sites in Lower Basin, Índia. Universal Journal of Environmental Research and Technology, v. 2, n. 5, p. 402-410, 2012. 
MCGRATH, S. P.; LOMBI, W.; GRAY, C. W.; CAILLE, N.; DUNHAM, S. J.; ZHAO, F. J. Field evaluation of $\mathrm{Cd}$ and $\mathrm{Zn}$ phytoextraction potential by the hyperaccumulators Thlaspi caerulescens and Arabidopsis halleri. Environmental Pollution, v. 141, n. 2, p. 115-125, 2006. https://doi.org/10.1016/j.envpol.2005.08.022

NAKAMURA, C. Y.; MARQUES, E.; VILELA, P.; ODA, T.; LIMA, L.; COSTA, R. AZEVEDO, I. C. Avaliação da qualidade da água subterrânea no entorno de um aterro sanitário. Revista Águas Subterrâneas, v. 28, n. 2, p. 28-40, 2014. https://doi.org/10.14295/ras.v28i2.27399

NACKE, H.; GONÇALVES JÚNIOR, A. C.; SCHWANTES, D.; NAVA, I. A.; STREY, L.; COELHO, G. F. Availability of heavy metals $(\mathrm{Cd}, \mathrm{Pb}$ and $\mathrm{Cr})$ in agriculture from commercial fertilizers. Archives of Environmental Contamination and Toxicology, v. 64, n. 3, p. 537-544, 2013. https://doi.org/10.1007/s00244-012-9867-z

NRIAGU, J. O.; PACYNA, J. M. Quantitative assessment of worldwide contamination of air, water and soils by trace metals. Nature, v. 333, p.134-139, 1988. https://doi.org/10.1038/333134a0

OLIVEIRA, S.; PASQUAL, A. Avaliação de parâmetros indicadores de poluição por efluente líquido de um aterro sanitário. Revista Engenharia Sanitária e Ambiental, v. 9, n. 3, p. 240-249, 2004.

RIBEIRO, E. V.; JUNIOR, A. P. M.; HORN, A. H.; TRINDADE, W. M. Metais pesados e qualidade da água do rio São Francisco no segmento entre Três Maria e Pirapora - MG: Índice de Contaminação. Revista Geonomos, v. 20, n. 1, p. 49-63, 2012.

ROCHA, C. H. B.; FREITAS, F. A.; SILVA, T. M. Alterações em variáveis limnológicas de manancial de Juiz de Fora devido ao uso da terra. Revista Brasileira de Engenharia Agrícola e Ambiental, v. 18, n. 4, p. 431-436, 2014.

ROCHA, C. H. B.; COSTA, H. F. Variação temporal de parâmetros limnológicos em manancial de abastecimento em Juiz de Fora, MG. Revista Brasileira de Recursos Hídricos, v. 20, n. 2, p. 543-550, 2015.

ROCHA, C. H. B.; PEREIRA, A. M. Análise multivariada para seleção de parâmetros de monitoramento em manancial de Juiz de Fora, Minas Gerais. Revista Ambiente \& Água, v. 11, n. 1, p. 176-187, 2016. http://dx.doi.org/10.4136/ambi-agua.1590

SANTANA, G. P.; BARRONCAS, P. de S. R. Estudo de metais pesados ( $\mathrm{Co}, \mathrm{Cu}, \mathrm{Fe}, \mathrm{Cr}, \mathrm{Ni}$, $\mathrm{Mn}, \mathrm{Pb}$ e $\mathrm{Zn}$ ) na Bacia do Tarumã-Açu Manaus - (AM). Revista Acta Amazônica, v. 37, n. 1, p. 111-118, 2007.

SILVA, L. S.; GALINDO, I. C. D. L.; NASCIMENTO, C. W. A. D.; GOMES, R. P.; FREITAS, L. D.; OLIVEIRA, I. A. D.; CUNHA, J. M. D. Heavy metals in waters used for human consumption and crop irrigation. Revista Ambiente \& Água, v. 13, n. 4, 2018. http://dx.doi.org/10.4136/ambi-agua.1999

SILVA, L. S.; GALINDO, I. C. L.; NASCIMENTO C. W. A.; GOMES, R. P.; CAMPOS M. C. C.; FREITAS, L.; OLIVEIRA, I. A. Heavy metal contents in Latosols cultivated with vegetable crops. Pesquisa Agropecuária Tropical, v. 46, p. 391-400, 2016. http://dx.doi.org/10.1590/1983-40632016v4641587 
VASCO, A. N.; BRITTO, F. B.; PEREIRA, A. P .S.; MÉLlO JÚNIOR, A. V. M.; GARCIA, C. A. B.; NOGUEIRA, L.C. Avaliação espacial e temporal da qualidade de água na sub bacia do rio Poxim, Sergipe, Brasil. Revista Ambiente \& Água, v. 6, n. 1, p. 118-30, 2011. http://dx.doi.org/10.4136/ambi-agua.178

WHO. Copper in Drinking-water: Background document for development of WHO Guidelines for Drinking-water Quality. Geneva, 2004. 23p.

WHO. Exposure to mercury: a major public health concern. Geneva, 2007. 4p. (Preventing disease through healthy environments).

WHO. Exposure to lead: a major public health concern. Geneva, 2010a. 6p. (Preventing disease through healthy environments).

WHO. Exposure to cadmium: a major public health concern. Geneva, 2010b. 4p. (Preventing disease through healthy environments).

WHO. Exposure to arsenic: a major public health concern. Geneva, 2010c. 5p. (Preventing disease through healthy environments).

YU, S.; WU, Q.; LI, Q.; GAO, J.; LIN, Q.; MA, J.; XU, Q.; WU, S. Anthropogenic land uses elevate metal levels in stream water in an urbanizing watershed. Science of the Total $\begin{array}{lllllll}\text { Environment, } & \text { v. } 488-489, \quad \text { n. } & 1, & \text { p. }\end{array}$ https://doi.org/10.1016/j.scitotenv.2014.04.061 